DOI: 10.17951/lrp. 2018.37.1.75-94

\author{
IWONA ZWIERZCHOWSKA
}

Uniwersytet Marii Curie-Skłodowskiej

\title{
(NIE)ŚWIADOMA DECYZJA, CZYLI O MOTYWACH WYBORU PRZEDSZKOLA MONTESSORI
}

\begin{abstract}
Streszczenie: Dynamiczne zmiany zachodzące we współczesnej rzeczywistości społecznej stawiają nowe wyzwania przed polskim szkolnictwem. Konieczność odejścia od głęboko zakorzenionej tradycji edukacyjnej i niedostosowanego do obecnych warunków modelu szkoły skłania do poszukiwania alternatywnych rozwiązań. W związku z tym od kilkunastu lat obserwuje się wzrost zainteresowania różnorodnymi ofertami edukacyjnymi, wśród których ważne miejsce zajmuje kształcenie zgodne z założeniami koncepcji pedagogicznej Marii Montessori. Oparcie realizowanego w placówkach montessoriańskich procesu edukacyjnego na aktywności dziecka, podmiotowe traktowanie wychowanka, respektowanie jego indywidualnych potrzeb, możliwości i zainteresowań, wspieranie jego wszechstronnego rozwoju staje się katalizatorem samorozwoju, samokształcenia i samowychowania, których tak bardzo oczekuje się od współczesnego pokolenia uczniów. Rosnąca popularność placówek montessoriańskich skłania jednak do postawienia pytania, na ile ich wybór jest efektem racjonalnej decyzji rodziców i faktycznego przekonania o wartości systemu pedagogicznego Montessori. Analiza materiału empirycznego zgromadzonego na potrzeby niniejszego opracowania ujawniła motywy, jakimi kierowali się badani rodzice, dokonując wyboru placówki przedszkolnej dla swojego dziecka, a także ich oczekiwania i opinie na temat edukacji realizowanej w przedszkolach wykorzystujących pedagogikę Marii Montessori.
\end{abstract}

Słowa kluczowe: edukacja przedszkolna, pedagogika Marii Montessori, przedszkole Montessori, wybór przedszkola

\section{WPROWADZENIE, CZYLI O POTRZEBIE EDUKACJI NA MIARĘ CZASÓW}

System pedagogiczny Marii Montessori stanowi jedną z najbardziej popularnych alternatywnych form edukacji, szczególnie edukacji dzieci w wieku przedszkolnym 
i wczesnoszkolnym. Pozostaje on w opozycji do tradycyjnej polskiej szkoły, która - mimo trwającej od wielu lat krytyki (por. Dudzikowa 2001; Klus-Stańska 2006, 2015; Kwieciński 1995; Lewowicki 1997; Mieszalski 1997; Szmidt 2005; Śliwerski 1993, 2013) - preferuje transmisyjny i adaptacyjny model kształcenia i wychowania, „wykształca umiejętności przystosowawcze, mentalność adaptacyjną, tworzy człowieka jednowymiarowego o orientacji zachowawczej, utrwala konformizm" (Pilch 2010, s. 32). Ten mało optymistyczny obraz szkolnej rzeczywistości obliguje do podejmowania działań reformatorskich i poszukiwania rozwiązań odpowiadających potrzebom i oczekiwaniom współczesnego człowieka i współczesnego społeczeństwa. Społeczeństwa, które funkcjonuje w świecie podlegającym nieustannej zmianie, w rzeczywistości określanej mianem płynnej nowoczesności, w której życie - jak konstatuje Zygmunt Bauman (2006, s. 152) - „[...] przypomina codziennie o powszechnej przemijalności wszystkiego bez wyjątku”.

Zjawiska i procesy charakteryzujące współczesną cywilizację, takie jak: globalizacja, wzrost liczby ludności, migracja, wielokulturowość, nasilające się nierówności społeczne, kurczenie się zasobów naturalnych, konflikty zbrojne, choroby cywilizacyjne, dynamiczny rozwój nowych technologii i Internetu, dominacja kultury popularnej i przekazów wizualnych, tabloidyzacja wielu sfer życia, prowadzą do wielkich przewartościowań, kulturowej uniformizacji oraz aksjologicznego rozedrgania i rzeczywiście wymagają od człowieka niezwykłej elastyczności, otwartości, kreatywności, samodzielności, umiejętności współpracy z innymi i negocjowania znaczeń, selekcjonowania i wartościowania informacji, sprawności komunikacyjnej i innych (Kołodziej 2013, s. 207-208).

Jednym $z$ kluczowych środowisk odpowiedzialnych za przygotowanie jednostek do życia w dzisiejszym świecie jest szkoła, która, aby właściwie spełniać przypisywane jej funkcje i realizować stawiane przed nią zadania, nie może „stać w miejscu" i nie reagować na zmiany polityczne, ekonomiczne czy społeczne zachodzące we współczesnej rzeczywistości. Co więcej, „[...] szkoła, aby sprostać wyzwaniom nowoczesnego świata, wymaga rozwoju oświaty i systemu kształcenia na wszystkich poziomach, aby pozwolił jej nie tylko sprostać przemianom, ale też zapewnił wszechstronny i harmonijny rozwój dzieci oraz młodzieży" (Surzykiewicz 2010, s. 451). Koniecznością wydaje się odejście od głęboko zakorzenionej tradycji edukacyjnej, zgodnie z którą - jak trafnie zauważa Małgorzata Żytko - uczeń jest silnie podporządkowany nauczycielowi (Pomianowska, Stańczyk 2015). Stąd postulat edukacji, w której centrum znajdzie się aktywnie działający uczeń, mający prawo wyboru i przejmujący odpowiedzialność za proces uczenia się. Nauczyciel natomiast zrezygnuje $\mathrm{z}$ dotychczasowej roli osoby kierującej procesem kształcenia na rzecz organizatora przestrzeni edukacyjnej. Słuszne wydaje się twierdzenie, że „jeśli szkoła ma dalej istnieć jako instytucja oferująca podstawy wykształcenia, 
musi dokonać się w niej przełom - system szkolny musi dostrzec, że klasa szkolna składa się z wielu indywidualności, mających różne potrzeby i oczekiwania" (Kołodziejczyk, Polak 2011, s. 66).

\section{SYSTEM PEDAGOGICZNY MONTESSORI JAKO ODPOWIEDŹ NA WSPÓŁCZESNE POTRZEBY EDUKACYJNE}

Nie ulega wątpliwości, że niedostosowany do obecnych warunków model szkoły wymaga radykalnej zmiany. W sposób dobitny podkreśla to Aleksander Nalaskowski, pisząc:

Edukację trzeba wymyśleć na nowo. Tę obecną, w której po uszy tkwimy, zarówno podstawową, jak i akademicką stworzyliśmy na nasz obraz i podobieństwo. Okazaliśmy się jednakże dość szpetnym modelem. Takie jest zatem i nasze dzieło. A więc wciąż jeszcze musimy szukać wzoru o większej urodzie niż nasze ego. To jedyne, czego nie musimy wymyślać, a jedynie znaleźć (Nalaskowski 2007, s. 25).

W związku z tym od kilkunastu lat obserwuje się wzrastające zainteresowanie różnorodnymi ofertami edukacyjnymi, w tym koncepcją pedagogiczną Marii Montessori, która „[...] sprzyja organizowaniu zadań rozwojowych wspomagających kształtowanie się ludzi samodzielnych, niezależnych, autonomicznych” (Bednarczuk 2016, s. 354). Oparcie realizowanego w placówkach montessoriańskich procesu edukacyjnego na aktywności dziecka, podmiotowe traktowanie dziecka, respektowanie jego indywidualnych potrzeb, możliwości i zainteresowań, wspieranie jego wszechstronnego rozwoju staje się katalizatorem samorozwoju, samokształcenia i samowychowania, których tak bardzo oczekuje się od dzisiejszego pokolenia uczniów.

Założenia koncepcji pedagogicznej Marii Montessori wdrażane są do praktyki edukacyjnej w wielu krajach świata od początku XX wieku. W Polsce zainteresowanie pedagogiką Montessori znalazło odzwierciedlenie m.in. w licznych publikacjach, powstających głównie w okresie międzywojennym. Przejawiało się ono także przez implementację idei i rozwiązań montessoriańskich do pracy placówek przedszkolnych. Sytuacja Polski po drugiej wojnie światowej, polityczna izolacja naszego kraju od kultury zachodnioeuropejskiej i amerykańskiej (por. Śliwerski 2009, s. 91) na długie lata zahamowała rozwój pedagogiki Marii Montessori. Odrodzenie zainteresowań montessoriańską koncepcją edukacji w Polsce dostrzega się wyraźnie na przełomie XX i XXI wieku. Powstają wówczas placówki różnych poziomów kształcenia, pracujące według koncepcji pedagogicznej Montessori, 
stowarzyszenia, ośrodki kształcenia i doskonalenia nauczycieli. Pedagogika Marii Montessori włączana jest w kształcenie akademickie, realizowane są badania naukowe dotyczące efektywności edukacji montessoriańskiej. Pojawiają się publikacje teoretyczne i metodyczne związane z edukacją w tym systemie (Centner-Guz, Zwierzchowska 2014). Sukcesywny wzrost popularności metody Montessori trwa do dnia dzisiejszego, co jest szczególnie ważne ze względu na fakt, że, jak stwierdza Jolanta Sajdera (2014, s. 354), „możliwość funkcjonowania obok siebie różnych rozwiązań edukacyjnych, a co za tym idzie - zróżnicowana oferta edukacyjna może stanowić zabezpieczenie przed zmonopolizowaniem oświaty przez państwo".

Funkcjonowanie coraz większej liczby przedszkoli i szkół wykorzysujących montessoriański model kształcenia implikuje podejmowanie badań obejmujących różne grupy podmiotów zaangażowanych w realizowany przez nie proces edukacyjny. Opublikowane dotychczas w Polsce wyniki eksploracji dotyczyły przede wszystkim osiągnięć rozwojowych i edukacyjnych dzieci kształconych w systemie Montessori (Bednarczuk 2007; Guz 2006; Sikorska 2010; Sikorska, Osmańska 2013; Surma 2013; Zdybel 2014), nauczyciela montessoriańskiego (Centner-Guz, Zwierzchowska 2009; Dąbrowska 2015; Tuszyńska-Bogucka 1999), opinii studentów, nauczycieli, rodziców na temat wybranych aspektów pedagogiki Montessori (Królica 2009; Lulek 2014; Surma 2009; Zwierzchowska 2016), osobowości absolwentów klas Montessori (Bednarczuk 2016). Ze względu na pewne ograniczenia, wynikające m.in. ze stosunkowo niewielkiej liczebności obejmowanych badaniami osób, zasadne wydaje się dalsze monitorowanie placówek montessoriańskich i dokonywanie ewaluacji realizowanego w nich procesu wychowania i kształcenia.

\section{BADANIA WŁASNE}

W ostatnich latach nastąpił wyraźny wzrost zainteresowania okresem dzieciństwa i wczesną edukacją dziecka. Świadomość znaczenia pierwszych lat życia człowieka dla jego przyszłego sukcesu edukacyjnego, zawodowego i osobistego rodzi potrzebę coraz wcześniejszego obejmowania dzieci instytucjonalnym wychowaniem i kształceniem. Wielu rodziców - przekonanych o wartości edukacji na szczeblu przedszkolnym - stara się znaleźć dla swojego dziecka placówkę świadczącą usługi na jak najwyższym poziomie. Pojawia się jednak pytanie o definicję dobrego przedszkola czy dobrej szkoły. W dyskusjach dotyczących jakości placówek edukacyjnych akcentowane są zwykle takie cechy, jak: podmiotowe traktowanie dziecka, nauczyciela, rodziców; postrzeganie dziecka jako indywidualności, respektowanie jego potrzeb, zainteresowań uzdolnień; wspieranie wszechstronnego rozwoju; stwarzanie możliwości podejmowania dialogu z innymi, wchodzenia 
w relacje interpersonalne; współpraca $\mathrm{z}$ rodziną oraz szerszym środowiskiem lokalnym; otwartość na wszystkie grupy społeczne (por. Grzeszkiewicz 2005, s. 253; Muchacka 2013, s. 152; Śliwerski 2013, s. 21). Jak trafnie zauważa Stanisław Juszczyk (2012, s. 77):

wczesny, instytucjonalny proces wychowania i nauczania dzieci, prawidłowo zaplanowany i zrealizowany, staje się podstawą organicznych umiejętności dziecka, sprzyjających jego dalszej edukacji, przeciwdziałaniu trudnościom w uczeniu się, a także prawidłowemu zachowaniu się na przyszłym rynku pracy.

Rodzice, doceniając wychowawcze i edukacyjne walory instytucji, jaką jest przedszkole, starają się znaleźć placówkę, która w największym stopniu będzie odpowiadała ich wizji miejsca zapewniającego warunki umożliwiające wspieranie rozwoju dziecka oraz organizację wysokiej jakości procesu wychowawczo-dydaktycznego. Jedną z ofert cieszących się dużą popularnością na rynku edukacyjnym jest model kształcenia zgodny z pedagogiką Marii Montessori. W Lublinie - będącym terenem badań analizowanych w ramach niniejszego artykułu - najstarsze przedszkolne i szkolne oddziały montessoriańskie funkcjonują od ponad 20 lat, a liczba grup Montessori nieustannie wzrasta. Nie powinno więc dziwić, że klasy montessoriańskie są obszarem eksploracji mających na celu m.in. diagnozę organizowanego w nich procesu edukacyjnego, warunków, w jakich on przebiega oraz jego efektywności.

Przedmiotem badań prezentowanych w niniejszym opracowaniu uczyniono decyzje rodziców o wyborze przedszkola Montessori dla swojego dziecka. Chcąc ocenić racjonalność dokonanego przez nich wyboru, poczyniono starania mające na celu poznanie ich opinii na temat edukacji w systemie montessoriańskim. W toku przeprowadzonych eksploracji starano się uzyskać odpowiedzi na następujące pytania, jakie są przyczyny wyboru przedszkola Montessori przez badanych rodziców, jaki jest poziom wiedzy rodziców na temat wybranych zagadnień związanych z pedagogiką Montessori, jakie są oczekiwania badanych rodziców wobec przedszkola i nauczyciela wychowawcy. Zgromadzony materiał empiryczny stanowi podstawę do rozstrzygnięcia, w jakim stopniu wybór placówki montessoriańskiej wynika z odczuwanych potrzeb i faktycznego przekonania do systemu pedagogicznego Montessori, a na ile jest dziełem przypadku, czy też podyktowany został modą na niekonwencjonalne modele kształcenia. Na potrzeby badań wykorzystano metodę sondażu diagnostycznego. Badania ankietowe przeprowadzono we wrześniu 2015 roku w trzech lubelskich przedszkolach (Przedszkole nr 18, Przedszkole nr 19 i Przedszkole nr 34). Objęto nimi rodziców, których dzieci w roku szkolnym 2015/2016 rozpoczęły edukację przedszkolną w grupach Montessori. Otrzymano 
zwrot 54 autorskich kwestionariuszy ankiety, które w 98\% zakwalifikowano do dalszych analiz (1 kwestionariusz odrzucono ze względu na niedostateczną liczbę odpowiedzi).

\section{WYNIKI BADAŃ}

Niewiele spraw jest dla rodziców tak istotnych, jak wybór właściwej placówki przedszkolnej czy szkolnej dla dziecka. Na rynku edukacyjnym, obok przedszkoli publicznych, funkcjonuje coraz większa liczba placówek prywatnych czy społecznych. Oferta „klasycznych” przedszkoli uzupełniana jest innymi formami wychowania przedszkolnego, a placówkom realizującym konwencjonalny model kształcenia coraz częściej towarzyszą przedszkola profilowane (artystyczne, ekologiczne, językowe, sportowe), wykorzystujące autorskie projekty i programy czy alternatywne koncepcje pedagogiczne (przedszkola montessoriańskie, daltońskie, waldorfskie/steinerowskie). W analizowanych badaniach skoncentrowano się na wyborach dokonywanych przez rodziców, którzy drogę rozwoju i edukacji swojego dziecka postanowili rozpocząć od placówki przedszkolnej typu Montessori.

Kluczową kwestią w ramach podjętego tematu było określenie przyczyn wyboru przez badanych rodziców przedszkola pracującego zgodnie z zasadami pedagogiki Marii Montessori. Dane dotyczące tego zagadnienia zestawiono w tabeli 1.

Tabela 1. Przyczyny wyboru przedszkola Montessori

\begin{tabular}{|l|c|c|}
\hline \multicolumn{1}{|c|}{ Przyczyna wyboru } & N=53 & \% \\
\hline Założenia systemu Montessori & 20 & 37,7 \\
\hline Opinie znajomych o przedszkolu & 12 & 22,6 \\
\hline Rozwijanie samodzielności dziecka & 8 & 15,1 \\
\hline Indywidualne, podmiotowe traktowanie dziecka & 8 & 15,1 \\
\hline Uczęszczanie starszych dzieci do placówki Montessori & 8 & 15,1 \\
\hline Zróżnicowanie wiekowe dzieci w grupie & 6 & 11,3 \\
\hline Szansa wszechstronnego rozwoju dziecka & 6 & 11,3 \\
\hline Rozwijanie zainteresowań dziecka & 5 & 9,4 \\
\hline Baza dydaktyczna przedszkola & 4 & 7,5 \\
\hline Lokalizacja przedszkola & 4 & 7,5 \\
\hline Inne & 15 & 28,3 \\
\hline
\end{tabular}

Źródło: opracowanie własne 
Analiza zgromadzonych wypowiedzi pozwala wnioskować, że największy odsetek respondentów, dokonując wyboru placówki montessoriańskiej, kierował się założeniami koncepcji pedagogicznej Marii Montessori. Przykładem takiego podejścia może być następująca wypowiedź:

Bliskie są nam założenia tej pedagogiki, m.in. szacunek dla indywidualności dziecka, otwartość na kreatywność i samodzielność, wspieranie w odkrywaniu i rozwijaniu własnych umiejętności, nauka w zgodzie z własnym tempem rozwoju, bez zadań opartych stricte na rywalizacji, swoboda w wyborze przedmiotów do pracy (Kwest. nr 37; rodzice trzyletniego chłopca; wykszt. wyższe).

Niestety, badani często ograniczali się do ogólnych odpowiedzi, nie określając szczegółowo, jakie przesłanki kształcenia i wychowania mieli na uwadze. Można jedynie przypuszczać, że u podstaw poszukiwań alternatywnej drogi edukacji dziecka wielokrotnie leżało niezadowolenie czy rozczarowanie tradycyjnymi rozwiązaniami stosowanymi w powszechnym modelu edukacji: „Nie do końca odpowiadają nam rozwiązania w tradycyjnym przedszkolu i szukaliśmy alternatywy, która dostępna jest w Lublinie" (Kwest. nr 42; rodzice trzyletniej dziewczynki; wykszt. wyższe). Niemal co czwarty ankietowany przyznał, że decydującą rolę w podjęciu decyzji o zapisie dziecka do danej placówki odegrały informacje, jakie uzyskał na jej temat od znajomych. Opinie innych rodziców okazały się więc istotnym wyznacznikiem jakości pracy przedszkola. Część respondentów jako podstawowe przyczyny dokonanego wyboru wskazała konkretne cele czy zasady edukacji montessoriańskiej, takie jak stymulowanie aktywności, rozwijanie samodzielności czy podmiotowy stosunek do dziecka: „[...] zależy nam na ukształtowaniu otwartego, zaradnego człowieka, który przez własne doświadczenia będzie potrafił radzić sobie w życiu i budować relacje społeczne” (Kwest. nr 6; rodzice czteroletniej dziewczynki i dwuipółletniego chłopca; wykszt. wyższe); „W placówkach Montessori w dziecku dostrzega się OSOBĘ w jej pełnym wymiarze - nie jest (jak w szkole) jednym z trybików mechanizmu, nie musi się dopasowywać do schematów, trybików, wyścigu szczurów" (Kwest. nr 12; rodzice trzyletniej dziewczynki; wykszt. wyższe). Niebagatelne znaczenie dla rodziców ma struktura grupy przedszkolnej - w świadomości respondentów zróżnicowana wiekowo grupa ułatwia, by nie powiedzieć wymusza, uwzględnianie w procesie edukacyjnym indywidualnego potencjału, potrzeb i możliwości dziecka, stwarzając tym samym warunki wszechstronnego rozwoju jednostki. Warto zauważyć, że indagowani przy wyborze przedszkola w niewielkim stopniu kierowali się lokalizacją placówki - tylko w pojedynczych przypadkach bliska odległość od miejsca zamieszkania lub pracy okazała się czynnikiem decydującym o wyborze. Za interesujące należy uznać, 
iż w kategorii „inne” znalazły się również odpowiedzi typu: „Przypadek” (Kwest. nr 27; rodzice trzyletniej dziewczynki; wykszt. wyższe) czy „Brak miejsca w innej placówce"1 (Kwest. nr 44; rodzice trzyletniego chłopca; wykszt. wyższe). Oznacza to, że decyzja niektórych rodziców o zapisaniu dziecka do placówki Montessori nie była efektem głębokich przemyśleń i refleksji, a w jednostkowych sytuacjach podyktowana była wręcz koniecznością.

W kontekście podjętej problematyki interesującą kwestią wydawało się określenie źródeł informacji na temat wybranego przedszkola i zasad jego działania (tabela 2).

Tabela 2. Źródła informacji o przedszkolu Montessori

\begin{tabular}{|l|c|c|}
\hline \multicolumn{1}{|c|}{ Źródło informacji } & $\mathbf{N = 5 3}$ & \% \\
\hline Znajomi & 25 & 47,2 \\
\hline Internet & 17 & 32,1 \\
\hline Studia & 7 & 13,2 \\
\hline Uczęszczanie starszych dzieci do przedszkola Montessori & 7 & 13,2 \\
\hline Inne & 5 & 9,4 \\
\hline Brak odpowiedzi & 1 & 1,9 \\
\hline
\end{tabular}

Źródło: opracowanie własne

Na podstawie zebranych danych można stwierdzić, że o funkcjonowaniu przedszkola Montessori niemal połowa ankietowanych dowiedziała się od znajomych. Istotnym źródłem informacji na ten temat okazał się także Internet, stanowiący dziś podstawowe medium komunikacji społecznej. Mniejszy, aczkolwiek znaczący, odsetek badanej populacji z tematem zlokalizowanych w Lublinie placówek montessoriańskich zetknął się w trakcie studiów. Wśród badanych znalazły się także osoby, które znały już przedszkole Montessori z autopsji, gdyż uczęszczały do niego ich starsze dzieci.

Fakt, że w objętej badaniami populacji znaleźli się zarówno rodzice niemający doświadczeń z grupami montessoriańskimi, jak i tacy, którzy - jak wcześniej wspomniano - poznali już specyfikę funkcjonowania tych oddziałów, pozwala przyjąć założenie o znacznym zróżnicowaniu zakresu posiadanej przez nich wiedzy na temat teorii i praktyki pedagogiki Marii Montessori. Wyniki uzyskane w tym zakresie przedstawia tabela 3 .

${ }^{1}$ Przedszkola lubelskie realizujące założenia koncepcji pedagogicznej Marii Montessori cieszą się dużym zainteresowaniem i na ogół nie wszystkie zgłaszane dzieci mają szansę rozpoczęcia w nich edukacji. W Przedszkolu nr 18 w Lublinie w okresie przeprowadzania badań (rok szkolny 2015/2016) funkcjonowała tzw. grupa popołudniowa pracująca w godz. 15.00-20.00, która - jako jedyna z oddziałów montessoriańskich (ze względu na godziny pracy) - dysponowała wolnymi miejscami. 
Tabela 3. Zakres wiedzy badanych rodziców na temat wybranych zagadnień dotyczących teorii i praktyki montessoriańskiej

\begin{tabular}{|c|c|c|c|c|c|c|c|c|}
\hline \multirow{3}{*}{ Zagadnienie } & \multicolumn{8}{|c|}{ Zakres posiadanej wiedzy } \\
\hline & \multicolumn{2}{|c|}{ duży } & \multicolumn{2}{|c|}{ przeciętny } & \multicolumn{2}{|c|}{ mały } & \multicolumn{2}{|c|}{ żaden } \\
\hline & $\mathbf{N}$ & $\%$ & $\mathbf{N}$ & $\%$ & $\mathbf{N}$ & $\%$ & $\mathbf{N}$ & $\%$ \\
\hline $\begin{array}{l}\text { Maria Montessori - jej życie i kariera } \\
\text { zawodowa }\end{array}$ & 9 & 17,0 & 23 & 43,4 & 19 & 35,8 & 2 & 3,8 \\
\hline $\begin{array}{l}\text { Poglądy Marii Montessori na temat dziecka } \\
\text { i jego rozwoju }\end{array}$ & 16 & 30,2 & 33 & 62,3 & 3 & 5,7 & 1 & 1,9 \\
\hline $\begin{array}{l}\text { Teoretyczne założenia systemu pedagogicz- } \\
\text { nego Montessori }\end{array}$ & 15 & 28,3 & 31 & 58,5 & 6 & 11,3 & 1 & 1,9 \\
\hline $\begin{array}{l}\text { Materiały dydaktyczne wykorzystywane } \\
\text { w oddziałach Montessori }\end{array}$ & 14 & 26,4 & 25 & 47,2 & 13 & 24,5 & 1 & 1,9 \\
\hline $\begin{array}{l}\text { Organizacja procesu wychowawczo-dydak- } \\
\text { tycznego w placówkach Montessori } \\
\text { (struktura grupy, organizacja zajęć, zasady } \\
\text { pedagogiczne) }\end{array}$ & 20 & 37,7 & 22 & 41,5 & 10 & 18,9 & 1 & 1,9 \\
\hline Ogółem & 74 & 27,9 & 134 & 50,6 & 51 & 19,2 & 6 & 2,3 \\
\hline
\end{tabular}

Źródło: opracowanie własne

Ogląd zebranego materiału badawczego wskazuje, że połowa badanych rodziców ocenia zakres posiadanej przez siebie wiedzy na temat wybranych zagadnień związanych z koncepcją pedagogiczną Marii Montessori jako przeciętny. Znaczny odsetek respondentów (28\%) jeszcze wyżej ocenia swoją wiedzę w omawianym temacie. Jednocześnie co piąty ankietowany przyznaje, że jego znajomość problematyki montessoriańskiej jest niewielka, a - co ciekawe - jeden $\mathrm{z}$ badanych wyjawia, że w ogóle nie orientuje się w analizowanych zagadnieniach. Z powyższego zestawienia tabelarycznego wynika, że tematem, w którym indagowani mają dość poważne braki informacyjne, jest biografia Marii Montessori. Mimo iż najwięcej respondentów uznało, że dysponuje przeciętnym stopniem wiedzy dotyczącej życia i kariery zawodowej Włoszki, to równocześnie niemal 40\% badanych deklaruje mały zasób orientacji w poruszanej kwestii. W świetle analiz uzyskanych wyników stwierdzono u rodziców wyraźne niedostatki w znajomości materiałów dydaktycznych wykorzystywanych w placówkach montessoriańskich. Wydaje się, że ankietowani w większym stopniu skupiają się na organizacji procesu wychowawczo-dydaktycznego w grupach Montessori. Bardziej zadowalające wyniki odnotowano również w ocenie zakresu posiadanej wiedzy na temat wizji dziecka, jaką miała autorka omawianej koncepcji pedagogicznej, a także teoretycznych założeń stworzonego przez nią systemu pedagogicznego. 
Kolejnym zadaniem realizowanym $\mathrm{w}$ ramach podjętych badań było ustalenie źródeł, z jakich rodzice czerpali wiedzę na temat specyfiki edukacji zgodnej z koncepcją pedagogiczną Marii Montessori (tabela 4).

Tabela 4. Źródła wiedzy badanych rodziców na temat edukacji według założeń Marii Montessori

\begin{tabular}{|l|c|c|}
\hline \multicolumn{1}{|c|}{ Źródło wiedzy } & N=53 & \% \\
\hline Internet & 43 & 81,1 \\
\hline Obserwacja i materiały informacyjne przedszkola & 14 & 26,4 \\
\hline Studia & 14 & 26,4 \\
\hline Opinie znajomych & 11 & 20,8 \\
\hline Literatura & 10 & 18,9 \\
\hline Inne & 3 & 5,7 \\
\hline
\end{tabular}

Źródło: opracowanie własne

Na podstawie zgromadzonych danych można stwierdzić, że informacje na temat kształcenia w systemie Montessori respondenci pozyskiwali przede wszystkim z Internetu. Znaczna część badanych rodziców wzbogaciła swoją wiedzę, dokonując bezpośredniej obserwacji funkcjonowania przedszkola montessoriańskiego oraz bazując na specjalnie opracowanych przez placówkę materiałach informacyjnych. Warto zauważyć, że średnio co czwarty ankietowany przyznał, iż z problematyką dotyczącą pedagogiki Marii Montessori zetknął się w trakcie studiów. Zbliżone liczbowo grupy stanowili badani, którzy jako źródła wiedzy dotyczącej teoretycznych założeń pedagogiki Montessori i ich egzemplifikacji we współczesnej rzeczywistości edukacyjnej podali opinie znajomych oraz literaturę przedmiotu.

Przy próbie określenia motywów wyboru przedszkola Montessori zasadne wydawało się ustalenie oczekiwań i nadziei, jakie badani rodzice wiążą z docelową placówką edukacyjną swojego dziecka (tabela 5).

Tabela 5. Oczekiwania badanych rodziców w stosunku do przedszkola Montessori

\begin{tabular}{|l|c|c|}
\hline \multicolumn{1}{|c|}{ Oczekiwania wobec przedszkola } & N=53 & \% \\
\hline Wspomaganie wszechstronnego rozwoju dziecka & 20 & 37,7 \\
\hline Zapewnienie bezpieczeństwa & 16 & 30,2 \\
\hline Zaspokajanie indywidualnych potrzeb dziecka & 9 & 17,0 \\
\hline Wspieranie rodziny w wychowaniu dziecka & 6 & 11,3 \\
\hline Rozwijanie samodzielności & 5 & 9,4 \\
\hline Realizacja założeń montessoriańskich & 5 & 9,4 \\
\hline
\end{tabular}




\begin{tabular}{|l|c|c|}
\hline \multicolumn{1}{|c|}{ Oczekiwania wobec przedszkola } & N=53 & \% \\
\hline $\begin{array}{l}\text { Zapewnienie bazy umożliwiającej rozwijanie zaintereso- } \\
\text { wań }\end{array}$ & 4 & 7,5 \\
\hline Przygotowanie do kolejnych szczebli edukacyjnych & 4 & 7,5 \\
\hline Rozwijanie kreatywności & 4 & 35,8 \\
\hline Inne & 19 & 3,8 \\
\hline Brak odpowiedzi & 2 & \\
\hline
\end{tabular}

Źródło: opracowanie własne

Zebrane i poddane analizie wypowiedzi dowodzą, że dla znacznej części badanej populacji podstawowe znaczenie ma wspieranie wszechstronnego rozwoju dziecka. Ważne z punktu widzenia rodziców jest także zapewnienie bezpieczeństwa: „Chcielibyśmy, aby nasze dziecko czuło się bezpieczne i szczęśliwe oraz aby z dnia na dzień przynosiło do domu jakąś nową wiedzę i doświadczenia" (Kwest. nr 39; rodzice czteroletniego chłopca; wykszt. wyższe). Respondenci oczekują, że wybrana przez nich placówka, realizując założenia pedagogiki Montessori, będzie stwarzała warunki umożliwiające zaspokajanie indywidualnych potrzeb dziecka oraz sprzyjające rozwijaniu jego samodzielności, ciekawości świata, kreatywności: „Nadzieja, że podstawowa idea, która przyświecała założycielce, nie zostanie gdzieś po drodze zgubiona. Oczekuję, iż wychowawca pomoże dziecku, zachęci je do pracy z pomocami dydaktycznymi i rozbudzi w nim ciekawość światem, który je otacza" (Kwest. $\mathrm{nr}$ 12; rodzice trzyletniej dziewczynki; wykszt. wyższe). Analiza zgromadzonych wypowiedzi utwierdza w przekonaniu, że ankietowani spodziewają się wsparcia ze strony przedszkola w realizacji funkcji pełnionych przez rodzinę, przede wszystkim wychowawczej i kształcącej: „Ponieważ uważamy, że rodzina jest środowiskiem, które najwcześniej kształtuje młodego człowieka, oczekujemy, że przedszkole będzie w tym procesie wspierało nas, realizując założenia Marii Montessori” (Kwest. nr 33; rodzice trzyletniej dziewczynki; wykszt. wyższe). Optymizmem napawają głosy rodziców, którzy - dzięki wcześniejszym doświadczeniom z placówką Montessori mają ukształtowane określone opinie na jej temat: „Jest to najlepsza droga rozwoju dziecka, którą zamierzam kontynuować na II poziomie" (Kwest. nr 40, rodzice czteroletniego chłopca; M - wykszt. wyższe; O - wykszt. średnie). Odpowiedzi tej grupy badanych na pytanie o ich oczekiwania wobec przedszkola często zamykały się w lapidarnych stwierdzeniach: „By nadal było tak super jak dotychczas” (Kwest. nr 27; rodzice trzyletniej dziewczynki; wykszt. wyższe). Ogólnie - na podstawie danych zaprezentowanych w tabeli 5 - można wysnuć wniosek o znacznym zróżnicowaniu oczekiwań badanej populacji w stosunku do wybranej placówki przedszkolnej (wysoki odsetek różnorodnych odpowiedzi ujętych w kategorii „inne”). 
Odrębne pytanie skierowane do ankietowanych rodziców dotyczyło nadziei, jakie wiążą z osobą nauczyciela ich dziecka. Rozkład odpowiedzi uzyskanych w tym zakresie przedstawia tabela 6 .

Tabela 6. Oczekiwania badanych rodziców wobec nauczyciela-wychowawcy

\begin{tabular}{|l|c|c|}
\hline \multicolumn{1}{|c|}{ Oczekiwania wobec nauczyciela } & $\mathbf{N = 5 3}$ & $\mathbf{1 8 , 9}$ \\
\hline Współpraca z rodzicami & $\mathbf{1 0}$ & 15,1 \\
\hline Indywidualne podejście do dziecka & 8 & 15,1 \\
\hline Profesjonalizm & 7 & 13,2 \\
\hline Zapewnienie dziecku opieki i bezpieczeństwa & 6 & 11,3 \\
\hline Wspieranie dziecka & 6 & 11,3 \\
\hline Akceptacja, szacunek dla dziecka & 6 & 11,3 \\
\hline $\begin{array}{l}\text { Diagnozowanie i rozwijanie predyspozycji } \\
\text { i zainteresowań dziecka }\end{array}$ & 5 & 9,4 \\
\hline Empatia, przyjazny stosunek do dziecka & 4 & 7,5 \\
\hline Realizacja zasad montessoriańskich & 4 & 7,5 \\
\hline Otwartość & 4 & 7,5 \\
\hline Komunikatywność & 4 & 7,5 \\
\hline Wyrozumiałość & 3 & 5,7 \\
\hline Cierpliwość & 11 & 20,8 \\
\hline Inne & 7 & 13,2 \\
\hline Brak odpowiedzi & & \\
\hline
\end{tabular}

Źródło: opracowanie własne

Oczekiwania respondentów wobec nauczyciela-wychowawcy odnoszą się zarówno do jego cech, jak i umiejętności, kompetencji, a także realizowanych przez niego zadań. Najwięcej badanych rodziców liczy na współpracę i partnerstwo w relacjach z nauczycielem: „Liczymy na otwarty i szczery kontakt, jesteśmy otwarci na rozmowę, wszelkie sugestie i pomoc" (Kwest. nr 37; rodzice trzyletniego chłopca; wykszt. wyższe); „Uczciwe informowanie o postępach bądź problemach dzieci" (Kwest. nr 33; rodzice trzyletniej dziewczynki; wykszt. wyższe). Znaczna część ankietowanych - znając specyfikę pracy placówek Montessori - oczekuje od nauczyciela indywidualnego, podmiotowego traktowania dziecka, uwzględniania w procesie kształcenia jego możliwości, potrzeb, rozwijania zdolności i zainteresowań: „Chcielibyśmy, by wychowawca był dla naszego dziecka wsparciem, służył wiedzą i pomocą oraz szanował jego indywidualność" (Kwest. nr 37; rodzice trzyletniego chłopca; wykszt. wyższe); „Jak najlepsze poznanie możliwości rozwojowych dziecka; rozwijanie jego indywidualnych predyspozycji, zainteresowań; wdrażanie 
zasad zgodnego współżycia w grupie; usamodzielnianie” (Kwest. nr 40, rodzice czteroletniego chłopca; M - wykszt. wyższe; O - wykszt. średnie); „Chciałabym, by przedszkole i nauczyciel-wychowawca zwracali szczególną uwagę na zainteresowania i uzdolnienia dziecka, aby dziecko traktowane było indywidualnie" (Kwest. nr 10; rodzice trzyletniej dziewczynki; wykszt. wyższe). Zapewnieniu wysokiej jakości opieki, wychowania i kształcenia sprzyja profesjonalizm nauczyciela. Wiedza i umiejętności pedagogiczne są niezbędne do przeprowadzenia właściwej diagnozy dziecka, poznania zarówno jego, jak i najbliższego mu środowiska, co jak wynika z wypowiedzi rodziców - jest istotną kategorią ich oczekiwań wobec nauczyciela: „Rozpoznawanie słabych i mocnych stron dziecka, wspieranie rozwoju dziecka, sugerowanie rodzicom sposobów pracy z dzieckiem w domu” (Kwest. nr 31; rodzice trzyletniej dziewczynki; wykszt. wyższe); „Profesjonalizm. Duża wiedza pedagogiczna” (Kwest. nr 53; rodzice pięcioletniej dziewczynki; wykszt. wyższe). Dodatkowo indagowani zwracali uwagę na cechy, jakimi powinien odznaczać się pedagog pracujący z ich dzieckiem. Wśród wymienianych właściwości znalazły się m.in. takie jak: otwartość, komunikatywność, wyrozumiałość, cierpliwość: „Wychowawca powinien być cierpliwy i dążyć do poznania i zrozumienia dziecka, tak by mógł mu skutecznie pomagać w poznawaniu świata” (Kwest. nr 6; rodzice czteroletniej dziewczynki i dwuipółletniego chłopca; wykszt. wyższe).

Nauczyciel przedszkola - poza interakcjami nawiązywanymi z dziećmi, które są głównym podmiotem jego oddziaływań edukacyjnych - pozostaje też w licznych relacjach z rodzicami podopiecznych. Ze względu na dużą wagę przywiązywaną do stosunków na płaszczyźnie przedszkole-dom rodzinny dziecka postanowiono określić wyobrażenia badanych na temat form współpracy z nauczycielem (tabela 7).

Tabela 7. Formy współpracy z nauczycielem preferowane przez badanych rodziców

\begin{tabular}{|l|c|c|}
\hline \multicolumn{1}{|c|}{ Formy współpracy } & $\mathbf{N = 5 3}$ & \% \\
\hline Kontakty indywidualne & 46,8 \\
\hline Imprezy okolicznościowe, wycieczki & 31 & 58,5 \\
\hline Internetowa strona przedszkola & 27 & 50,9 \\
\hline Spotkania ze specjalistami & 25 & 47,2 \\
\hline Zajęcia otwarte & 22 & 41,5 \\
\hline Zebrania grupowe & 20 & 37,7 \\
\hline Kącik dla rodziców & 7 & 13,2 \\
\hline Kontakt telefoniczny lub mailowy & 6 & 11,3 \\
\hline Brak preferencji w zakresie form współpracy & 2 & 3,8 \\
\hline
\end{tabular}

Źródło: opracowanie własne 
Zgromadzony materiał empiryczny wskazuje, że zdecydowana większość respondentów oczekuje $\mathrm{w}$ ramach współdziałania ze środowiskiem przedszkolnym przede wszystkim indywidualnych kontaktów z nauczycielem. To właśnie spotkania face to face i prowadzone w ich trakcie rozmowy są według rodziców najlepszym sposobem wymiany informacji na temat dziecka, poszerzania wiedzy pedagogicznej oraz ustalania z nauczycielem wspólnej strategii działania w zakresie wspomagania rozwoju i edukacji dziecka. Poza bezpośrednimi kontaktami indywidualnymi dużą popularnością wśród badanych cieszyły się imprezy okolicznościowe i wycieczki, które stanowią doskonałe okazje do bliższej integracji, służą wzajemnemu poznaniu dzieci, członków ich rodzin i personelu przedszkola oraz zacieśnieniu więzi między nimi. Cenionym przez ankietowanych sposobem współpracy okazała się także internetowa strona przedszkola, która w dzisiejszej dobie jest podstawowym źródłem informacji o samej placówce, mających w niej miejsce wydarzeniach i aktualnościach. Niemal połowa badanych rodziców deklaruje chęć udziału w spotkaniach ze specjalistami, np. psychologiem, logopedą. Niewiele mniej respondentów wśród pożądanych form współpracy z nauczycielem wymienia zajęcia otwarte, które dają możliwość zapoznania się z osiągnięciami dziecka, jego zachowaniem w przedszkolu i relacjami z rówieśnikami. Znaczna część indagowanych wskazuje na zebrania grupowe, które pełnią zwykle funkcję informacyjną i dotyczą spraw organizacyjnych związanych z funkcjonowaniem placówki. Duże zaangażowanie badanych we wskazywanie preferowanych sposobów współdziałania z nauczycielem-wychowawcą rokuje nadzieje na owocną i efektywną współpracę domu rodzinnego dziecka ze środowiskiem przedszkolnym.

\section{PODSUMOWANIE}

Wyniki przeprowadzonych analiz wskazują, że zdecydowana większość badanych rodziców wybiera dla swojego dziecka przedszkole Montessori, kierując się racjonalnymi względami. $Z$ deklaracji respondentów wynika, że u podstaw podjęcia takiej, a nie innej decyzji leży identyfikacja z założeniami koncepcji pedagogicznej Montessori. Znaczna część badanych przyznaje także, że niebagatelną rolę $\mathrm{w}$ rozstrzygnięciu dylematu dotyczącego wyboru określonego przedszkola odgrywają rekomendacje innych rodziców. To właśnie znajomi są dla niemal połowy indagowanych podstawowym źródłem informacji na temat funkcjonowania montessoriańskiej placówki przedszkolnej. Trzeba jednak podkreślić, że istotnym czynnikiem determinującym podjęcie decyzji o zapisaniu dziecka do przedszkola Montessori jest (deklarowana) wiedza i świadomość ankietowanych na temat organizacji pracy zgodnej z założeniami pedagogiki Marii Montessori. Na podkreślenie 
zasługuje, iż $1 / 4$ badanych rodziców z problematyką montessoriańską spotkała się w trakcie własnego kształcenia akademickiego. Wybór placówki edukacyjnej dla dziecka wiąże się z określonymi oczekiwaniami wobec przedszkola i zatrudnionego w nim personelu, przede wszystkim kadry pedagogicznej. Badani rodzice wyrażają nadzieję, że środowisko przedszkolne będzie stymulowało wszechstronny rozwój wychowanka, jego aktywność i naturalną ciekawość świata, zatroszczy się o bezpieczeństwo i zapewni realizację indywidualnych potrzeb dziecka, będzie umożliwiało rozwijanie jego samodzielności i kreatywności.

Wiele oczekiwań, zarówno w stosunku do instytucji przedszkola, jak i do nauczyciela, wydaje się niemożliwa do realizacji w dominującym konwencjonalnym modelu kształcenia. Rodzice, zdając sobie sprawę z deficytów i niedoskonałości polskiego systemu oświaty, poszukują rozwiązań, które umożliwią faktyczną poprawę jakości edukacji. Niestety, ich działania często napotykają opór, gdyż, jak konstatuje Bogusław Śliwerski (2009, s. 317):

[...] „przekleństwem” polskiej edukacji stają się wszelkie rozwiązania alternatywne, innowacje, eksperymenty pedagogiczne, solą w oku stają się szkolnictwo niepubliczne i alternatywne formy wychowania przedszkolnego. Każda odmienność od powszechnie obowiązujących rozwiązań jest atakowana z bardzo różnych powodów - ideologicznych, religijnych, psychologicznych, społecznych, pedagogicznych.

Do grona pedagogów pesymistycznie oceniających szanse zreformowania polskiego szkolnictwa należy także Zofia Aleksandra Kłakówna (2014, s. 22), która przyznaje: „Nie sądzę, by polska szkoła mogła zmienić się na lepsze z centralnego politycznego nadania, które hołduje na dodatek myśli, że wszyscy mają być kształceni tak samo, w takich samych zakresach oraz równie długo”. W ciemnych barwach przyszłość polskiej edukacji widzi również m.in. Dorota Klus-Stańska (2010), uznająca, że szkoła w naszym kraju zmierza ku przepaści.

Wobec zasygnalizowanej krytyki, pod którą podpisuje się znaczna część środowiska naukowego, cenne wydają się alternatywne inicjatywy edukacyjne, podejmowane zwykle przez nauczycieli, rodziców czy przedstawicieli środowiska lokalnego. Jak zaznacza Beata Przyborowska (2013, s. 45), ruchy alternatywne nasilające się w Polsce zwłaszcza po 1989 roku miały na ogół charakter społeczny, oddolny i nawiązywały do idei i dokonań Celestyna Freineta, Aleksandra Kamińskiego, Janusza Korczaka, Marii Montessori, Rudolfa Steinera. Nasuwa się w tym miejscu pytanie, czy alternatywą dla niespełniającego współczesnych oczekiwań tradycyjnego modelu kształcenia i wychowania może być system pedagogiczny Montessori. Oparcie realizowanego w placówkach montessoriańskich procesu edukacyjnego na aktywności i wewnętrznej motywacji dziecka, uwzględnienie jego potrzeb oraz 
indywidualnych możliwości rozwojowych, zainteresowań i predyspozycji, odejście od nauczania klasowo-lekcyjnego na rzecz samodzielnego uczenia się (głównie przez zdobywanie doświadczeń i konstruowanie wiedzy), zmiana roli nauczyciela $\mathrm{z}$ kierującego procesem nauczania na wspierającego dziecko, odpowiedzialnego za tworzenie środowiska inspirującego i stymulującego ciekawość poznawczą dziecka, podmiotowe traktowanie dziecka, obdarzanie je szacunkiem, zapewnienie mu poczucia bezpieczeństwa oraz wolności i autonomii będących warunkami aktywnego uczenia się to niewątpliwe wartości pedagogiki Montessori, dzięki którym pozostaje ona wciąż aktualna i zgodna $z$ najnowszymi ustaleniami i teoriami naukowymi (por. Miksza 2009, s. 144; Guz 2015, s. 13). Wydaje się, że placówka przedszkolna czy szkolna pracująca zgodnie z założeniami koncepcji pedagogicznej Marii Montessori ma szanse sprostać wymaganiom, oczekiwaniom i potrzebom jednostkowym (dzieci, rodziców, nauczycieli), a także społecznym (rówieśników, grup społecznych, środowiska lokalnego, szeroko rozumianego społeczeństwa). Niezależne jednak od argumentów zwolenników i przeciwników pedagogiki Montessori konieczna jest dalsza demonopolizacja państwa w dziedzinie edukacji przejawiająca się wzrostem różnorodności placówek i instytucji na mapie rynku edukacyjnego. Umożliwi to spełnienie postulatu zawartego w Europejskiej karcie praw i obowiązków rodziców, zgodnie z którym: „Rodzice mają prawo wyboru takiej drogi edukacji dla swoich dzieci, która jest najbliższa ich przekonaniom i wartościom uznawanym za najważniejsze dla rozwoju ich dzieci. Rodzice mają obowiązek dokonania świadomego wyboru drogi edukacyjnej, jaką ich dzieci powinny zmierzać".

\section{LITERATURA}

Bednarczuk B., 2016, Osobowość autorska absolwentów klas Montessori w perspektywie doświadczeń i celów życiowych. Kraków, Oficyna Wydawnicza Impuls.

Centner-Guz M., Zwierzchowska I., 2009, Stres zawodowy nauczycieli pracujacych w oddziałach Montessori. W: B. Surma (red.), Dziecko i dorosly w koncepcji pedagogicznej Marii Montessori - teoria i praktyka. Łódź-Kraków, Wydawnictwo Palatum, Wydawnictwo Wyższej Szkoły Filozoficzno-Teologicznej Ignatianum, 149-164.

Centner-Guz M., Zwierzchowska I., 2014, Renesans pedagogiki Marii Montessori w Polsce? W: A. Karpińska, A. Szwarc (red.), Wybrane problemy dydaktyki w wymiarze teoretyczno-praktycznym. Warszawa, Wydawnictwo Akademickie Żak, 265-278.

Dąbrowska M., 2015, Kompetencje nauczycieli do prowadzenia obserwacji dzieci w placówkach Marii Montessori. W: E. Ogrodzka-Mazur, U. Szuścik, A. Mincza- 
kowska (red.), Edukacja małego dziecka, t. 8: Przedszkole - przemiany instytucji i jej funkcji. Kraków, Oficyna Wydawnicza Impuls, 133-142.

Dudzikowa M., 2001, Mit o szkole jako miejscu „wszechstronnego rozwoju” ucznia.

Kraków, Oficyna Wydawnicza Impuls.

Grzeszkiewicz B., 2005, Rola przedszkola w przygotowaniu startu edukacyjnego.

W: S. Guz, J. Andrzejewska (red.), Wybrane problemy edukacji dzieci w przedszkolu i szkole. Lublin, Wydawnictwo UMCS, 253-260.

Guz S., 2015, Edukacja w systemie Marii Montessori. Wybrane obszary kształcenia,

t. 1. Lublin, Wydawnictwo UMCS.

Juszczyk S., 2012, Przestrzenie życia i edukacji dziecka w społeczeństwie wiedzy.

W: G. Kryk, M. Szepelawy (red.), Edukacyjne dylematy dzieciństwa. Racibórz, Wydawnictwo Państwowej Wyższej Szkoły Zawodowej w Raciborzu, 65-80.

Klus-Stańska D., 2006, Behawiorystyczne źródła myślenia o nauczaniu, czyli siedem grzechów głównych wczesnej edukacji. W: D. Klus-Stańska, E. Szatan. D. Bronk (red.), Wczesna edukacja. Między schematem a poszukiwaniem nowych ujęć teoretycznobadawczych. Gdańsk, Wydawnictwo Uniwersytetu Gdańskiego.

Klus-Stańska D., 2015, Dezintegracja tożsamości $i$ wiedzy jako proces i efekt edukacji wczesnoszkolnej. W: D. Klus-Stańska (red.), (Anty)edukacja wczesnoszkolna. Kraków, Oficyna Wydawnicza Impuls, 24-60.

Klus-Stańska D., 2010, Ciagłość i zmiana czy bierność i niekontrolowane odruchy w którym kierunku zmierza szkoła? W: J. Surzykiewicz, M. Kulesza (red.), Ciągłość i zmiana $w$ edukacji szkolnej - społeczne $i$ wychowawcze obszary napięć. Łódź, Wydawnictwo Uniwersytetu Łódzkiego, 35-49.

Kłakówna Z.A., 2014, Czy polska szkoła ma szansę na zmianę? W: R. NowakowskaSiuta (red.), Edukacja alternatywna na rzecz demokratyzacji procesu ksztatcenia. Kraków, Oficyna Wydawnicza Impuls, 13-23.

Kołodziej P., 2013, Szkoła w świecie pozoru. W: M. Dudzikowa, K. Knasicka-Falbierska (red.), Sprawcy i/lub ofiary działań pozornych w edukacji szkolnej. Kraków, Oficyna Wydawnicza Impuls, 204-220.

Kołodziejczyk W., Polak M., 2011, Jak będzie zmieniać się edukacja? Wyzwania dla polskiej szkoły i ucznia. Warszawa, Instytut Obywatelski.

Królica M., 2009, Znajomość wśród nauczycieli przedszkoli tez pedagogiki Marii Montessori i możliwości ich realizacji. W: B. Surma (red.), Pedagogika Marii Montessori w Polsce i na świecie. Łódź-Kraków, Wydawnictwo Palatum, Wydawnictwo Wyższej Szkoły Filozoficzno-Teologicznej Ignatianum, 121-129.

Kwieciński Z., 1995, Dynamika funkcjonowania szkoły: studium empiryczne z socjologii edukacji. Toruń, Wydawnictwo UMK.

Lewowicki T., 1997, Przemiany oświaty: szkice o ideach i praktyce edukacyjnej. Warszawa, Wydawnictwo Żak. 
Lulek B., 2014, W poszukiwaniu nowych rozwiąań w edukacji - rodzice i nauczyciele o systemie Marii Montessori. W: B. Lulek, Ł. Reczek-Zymróz, Rodzina i szkoła w zmieniającej się przestrzeni edukacyjnej. Dylematy czasu przemian. Rzeszów, Bonus Liber Wydawnictwo i Drukarnia Diecezji Rzeszowskiej, 257-308.

Mieszalski S., 1997, O przymusie i dyscyplinie w klasie szkolnej. Warszawa, WSiP.

Miksza M., 2009, Wartości pedagogiki Marii Montessori. Rola Polskiego Stowarzyszenia Montessori w propagowaniu jej idei. W: B. Surma (red.), Pedagogika Marii Montessori w Polsce i na świecie. Łódź-Kraków, Wydawnictwo Pallatum, Wydawnictwo Wyższej Szkoły Pedagogiczno-Filozoficznej Ignatianum.

Muchacka B., 2013, Organizowanie uczenia się dzieci w zabawie. W: E. Dolata, S. Pusz (red.), Wczesna edukacja dziecka. Implikacje do praktyki pedagogicznej. Rzeszów, Wydawnictwo Uniwersytetu Rzeszowskiego, 149-161.

Nalaskowski A., 2007, Wymyślmy to! W: B. Śliwerski (red.), Pedagogika alternatywna. Postulaty projekty i kontynuacje, t.1. Kraków, Oficyna Wydawnicza Impuls, 19-25. Pilch T., 2010, Społeczeństwo wobec szkoły - szkoła wobec przyszłości. Rozważania o polskiej polityce oświatowej. W: J. Surzykiewicz, M. Kulesza (red.), Ciągłość i zmiana $w$ edukacji szkolnej - społeczne $i$ wychowawcze obszary napięć. Łódź, Wydawnictwo Uniwersytetu Łódzkiego, 21-33.

Pomianowska M., Stańczyk M., Nadszedł czas zmian w edukacji. „Dyrektor Szkoły” 2015, nr 9, 14-17.

Przyborowska B., 2013, Pedagogika innowacyjności. Między teorią a praktyką. Toruń, Wydawnictwo Naukowe UMK.

Sajdera J., 2014, Edukacja przedszkolna jako sprawdzian dla zaangażowanego społeczeństwa. W: R. Nowakowska-Siuta (red.), Edukacja alternatywna na rzecz demokratyzacji procesu kształcenia. Kraków, Oficyna Wydawnicza Impuls, 351-364.

Sikorska I., Osmańska I., 2013, Czy montessoriański przedszkolak stanie się kreatywnym nastolatkiem? Doświadczenia średniego dzieciństwa a postawa twórcza adolescentów. „Edukacja Elementarna w Teorii i Praktyce”, nr 4 (30), 91-108.

Surma B., 2009, Rola nauczyciela w koncepcji pedagogicznej Marii Montessori w opinii studentek wychowania przedszkolnego. W: B. Surma (red.), Dziecko i dorosły w koncepcji pedagogicznej Marii Montessori - teoria i praktyka. Łódź-Kraków, Wydawnictwo Palatum, Wydawnictwo Wyższej Szkoły Filozoficzno-Teologicznej Ignatianum, 137-148.

Surma B., 2013, Gotowość szkolna do uczenia się matematyki dzieci sześcioletnich w przedszkolu Montessori - raport z badań. „Edukacja Elementarna w Teorii i Praktyce", nr 2 (28), 35-56.

Surzykiewicz J., 2010, Na drodze do idealnej szkoły - innowacja, rozwój i ocena jakości $w$ świetle międzynarodowej literatury. W: J. Surzykiewicz, M. Kulesza (red.), 
Ciągłość i zmiana w edukacji szkolnej - społeczne i wychowawcze obszary napięć. Łódź, Wydawnictwo Uniwersytetu Łódzkiego, 419-452.

Szmidt K.J., 2005, Współczesne koncepcje wychowania do kreatywności i nauczania twórczości: przegląd stanowisk polskich. W: K.J. Szmidt (red.), Dydaktyka twórczości. Koncepcje - rozwiązania - problemy. Kraków, Oficyna Wydawnicza Impuls, 19-29. Śliwerski B., 1993, Wyspy oporu edukacyjnego. Kraków, Oficyna Wydawnicza Impuls. Śliwerski B., 2009, Problemy współczesnej edukacji. dekonstrukcja polityki oświatowej III RP. Warszawa, Wydawnictwa Akademickie i Profesjonalne.

Śliwerski B., 2013, Zagubione cele polskiej edukacji. W: E. Dolata, S. Pusz (red.), Wczesna edukacja dziecka. Implikacje do praktyki pedagogicznej. Rzeszów, Wydawnictwo Uniwersytetu Rzeszowskiego, 13-22.

Waloszek D., 2011, Stracone złudzenia, czyli 40 lat poszukiwań miejsca w edukacji dla dzieci w wieku przedszkolnym. „Kwartalnik Pedagogiczny”, nr 1, 11-32.

Zwierzchowska I., 2015, Niepubliczna edukacja przedszkolna - alternatywa czy konieczność? W: S. Guz, M. Centner-Guz, I. Zwierzchowska (red.), W trosce o rozwój i wczesną edukację dziecka. Lublin, Wydawnictwo UMCS, 55-73.

Zwierzchowska I., 2016, Theory and Practice of Maria Montessori's Pedagogy in the Assessment of Future Teachers of Early Childhood Education. W: M. Chepil, A.M. Żukowska, O. Karpenko (red.), In the Sphere of Education and Artistic Work. Drohobych, Drohobych Ivan Franko State Pedagogical University, 39-48.

Prawa rodziców, opublikowano: https://men.gov.pl/zycie-szkoly/rady-rodzicow/prawarodzicow-2.html [dostęp: 28.11.2015].

\title{
(UN)CONSCIOUS DECISION - THAT IS ABOUT THE MOTIVES FOR CHOOSING A MONTESSORI KINDERGARTEN
}

\begin{abstract}
Dynamic changes taking place in the contemporary social reality pose new challenges for Polish schools. The necessity to depart from a deep-rooted educational tradition and a school model which does not suit the current conditions prompts the search for alternative solutions. Consequently, for several years there has been an increase in interest in various educational offers, and education in line with the assumptions of Maria Montessori's pedagogical concept has an important place among them. The educational process realised in Montessori institutions based on the child's activity, subjective treatment of the pupil, respect for his individual needs, abilities and interests, support for his versatile development become a catalyst for self-development, self-education and self-training, which are so much expected from the contemporary generation of students. However, the growing popularity of Montessori institutions raises the question of how much their choice is the result of parents' rational decision and real conviction about the value of the Montessori education system. The
\end{abstract}


analysis of the empirical material gathered for this study revealed the surveyed parents' motives for selecting a kindergarten facility for their child, as well as their expectations and opinions about education in the kindergarten working on the basis of Maria Montessori pedagogy.

Keywords: kindergarten education, Maria Montessori pedagogy, Montessori kindergarten, kindergarten choice 